\title{
PENGARUH PAPARAN MEDAN MAGNET EXTREMELY LOW FREQUENCY (ELF) TERHADAP PERUBAHAN PH PADA PROSES FERMENTASI BIJI KOPI LANANG (PEABERRY) KERING
}

\author{
Mamik Purbawati*, Sudarti, Firdha Kusuma A. A.
}

Program Studi S1 Pendidikan Fisika, Fakultas Keguruan dan Ilmu Pendidikan, Universitas Jember

Jl. Kalimantan Tegal Boto No.37, Krajan Timur, Sumbersari, Jember e-mail ${ }^{* 1}$ : mamikpurbawati@gmail.com

\begin{tabular}{c|c|r|r} 
Diterima 27 Juni 2021 & Direvisi 2 September 2021 & Disetujui 4 September 2021 & Dipublikasikan 19 September 2021 \\
\hline \multicolumn{4}{|c|}{ https://doi.org/10.33369/jkf.4.2.129-136 } \\
\hline
\end{tabular}

\begin{abstract}
ABSTRAK
Kopi lanang (Peaberry) merupakan jenis kopi yang mempunyai biji berkeping satu (monokotil) dengan kafein yang kadarnya lebih tinggi jika dibandingkan dengan kopi jenis lain. Kadar kafein yang tinggi pada biji kopi bisa diturunkan dengan proses fermentasi kopi. Penelitian ini mempunyai tujuan untuk mengetahui pengaruh paparan medan magnet ELF (Extremely Low Frequency) terhadap perubahan $\mathrm{pH}$ pada proses fermentasi biji kopi lanang (Peaberry) kering jenis robusta dengan penambahan enzim $\alpha$-amilase. Jenis penelitian yang digunakan yaitu penelitian eksperimen dengan desain Rancangan Acak Lengkap (RAL) bertujuan mengkaji pengaruh perlakuan dengan pengulangan percobaan. Penelitian ini memiliki tujuh kelompok sampel meliputi kelompok kontrol dan kelompok eksperimen variasi intensitas paparan medan manet ELF sebesar $200 \mu \mathrm{T}$ dan $300 \mu \mathrm{T}$ dan variasi lama pemaparan 30 menit, 60 menit dan 90 menit. Pengukuran data hasil penelitian diambil setelah pemaparan yaitu pada hari ke-1 sampai hari ke-5 selama proses fermentasi berlangsung. Hasil penelitian menyatakan bahwa paparan medan magnet ELF berpengaruh terhadap perubahan $\mathrm{pH}$ pada proses fermentasi biji kopi lanang (Peaberry) kering jenis robusta yang ditunjukkan dengan variasi bentuk grafik. Pemaparan medan magnet ELF dengan intensitas $200 \mu \mathrm{T}$ dan lama pemaparan 30 menit dapat menurunkan $\mathrm{pH}$ secara signifikan, sedangkan intensitas $200 \mu \mathrm{T}$ dan lama waktu paparan 90 menit dapat menaikkan $\mathrm{pH}$ secara signifikan pada proses fermentasi biji kopi lanang (Peaberry) kering jenis robusta.
\end{abstract}

Kata kunci : Medan magnet ELF, Fermentasi, Kopi Lanang (Peaberry), pH

\begin{abstract}
Peaberry coffee is a type of coffee that has a single bean (monocotyle) with a higher levels of caffeine if compared whith other types of coffee. High levels of caffeine in coffee beans can be reduced by the coffee fermentation process. The study aims to examine the effect of exposure to the ELF (Extremely Low Frequency) magnetic field on changes of $\mathrm{pH}$ in the fermentation process of robusta peaberry dray coffee beans with the addition of $\alpha$-amylase enzyme. The type of research that use in the experimental reseacrh with a randomized subject post test only control grup design, it aiming to examine the effect of treatment by repeating the experiment. This study include seven sample groups covering the control group and the experimental group variation in the intensity of ELF magnetic field with $200 \mu \mathrm{T}$ and $300 \mu \mathrm{T}$ and variation of a length 30, 60, 90 minutes. Meansurement of the data research taken after exposure that is on the day one to day five during the fermentation process. The result of the study suggest that exposure to ELF magnetic field has an effect on the $\mathrm{pH}$ fermentation prosess of dried peaberry coffee beans, which was shown variations of the shape of the graph. Exposure to the ELF magnetic field with an intensity of $200 \mu \mathrm{T}$ and the length of 30 minutes can significantly decrease the $\mathrm{pH}$, while the intensity of $200 \mu \mathrm{T}$ and the length of 30 minutes can significantly increase the $\mathrm{pH}$ in the fermentation process of dried robusta paberry coffee beans.
\end{abstract}

Keywords : ELF magnetic field, Fermentation, Peaberry Coffee, $\mathrm{pH}$

\section{PENDAHULUAN}

Kopi (Coffea $s p$ ) merupakan tanaman perkebunan yang tergolong dalam genus Coffea dan famili Rubiaceae. Kopi di Indonesia menjadi produk unggulan dalam perdagangan Internasional, Internasional Coffee Agreement 2007 menyatakan bahwa Indonesia menjadi salah satu empat 
negara pengekspor kopi terbesar dunia (1). Kopi di Indonesia sebesar $77 \%$ produksinya untuk memenuhi permintaan ekspor dan lainnya untuk pasar domestik, daerah penghasil kopi terbesar di Indonesia tersebar di beberapa provinsi seperti, Sumatra Selatan, Lampung, Aceh, Sumatra Utara dan Jawa Timur (Data Statistik Kopi Indonesia 2017). Buah kopi mempunyai empat bagian yaitu Pulp, lapisan lendir (mucilage), biji kopi (endosperm) dan kulit biji (endokarp). Biji kopi yang berkualitas berdasarkan SNI 01-2907-2008 memiliki syarat mutu umum yakni tidak ada serangga hidup, tidak berbau busuk, kadar air maksimal $12 \%$ dan kadar kotoran maksimal 0,5\%. Biji kopi mengandung beberapa unsur yang terdiri dari kafein, trigonelin, sukrosa, monosakarida, asam klorogenat dan asam nikotinat (2). Kafein merupakan komponen kopi yang dianggap sebagai doping alami (3). Biji kopi mengandung kadar kafein berkisar 1-2,5\% dan setiap $100 \mathrm{ml}$ dalam satu cangkir kopi mengandung 80-100 mg kafein, Generally Recognized as Save menyatakan bahwa dosis maksimum kafein yang dapat diterima manusia sekitar 400 mg per hari secara oral (4).

Kafein memiliki beberapa manfaat secara klinis, seperti stimulasi otot jantung dan menstimulasi susunan saraf pusat, relaksasi otot polos, akan tetapi kafein yang dikonsumsi secara berlebihan dapat berdampak negatif bagi sirkulasi tubuh (5) seperti gangguan lambung, meningkatkan debar jantung, gelisah, tangan gemetar, ingatan berkurang, risiko penyakit kardiovaskular, hipertensi, dan meningkatkan kolesterol (4). Kafein dapat ditemukan pada kopi Lanang, jenis kopi ini mempunyai kadar kafein yang lebih tinggi dibandingkan dengan jenis kopi yang lain (6). Kadar kafein kopi lanang jenis arabika 1,20\% dan robusta 2,01\% (7). Kopi lanang (Peaberry) memiliki bentuk biji yang unik, umumnya kopi berbiji dua, namun untuk kopi lanang biji kopinya hanya satu. Namun, kopi lanang mempunyai cita rasa yang khas (8). Kopi lanang memiliki beberapa manfaat dapat meningkatkan vitalitas seksual pada hewan mencit (9), dapat meningkatkan stamina ekstra pada pria, dan meningkatkan aktivitas hingga larut malam (10). Akan tetapi, tingginya kafein pada kopi lanang dapat berdampak negatif pada tubuh sehingga perlu dilakukan pengurangan kadar kafein yang dapat dilakukan dengan cara fermentasi (5).

Teknik pengolahan kopi secara fermentasi dikenal dengan proses dekafeinasi kopi (11). Fermentasi dapat menurunkan kadar kafein, menurunkan kadar asam (12), menurunkan $\mathrm{pH}$ (13) dan membentuk karakter cita rasa kopi akibat adanya asam organik, gula reduksi dan asam amino (14). Proses fermentasi dilakukan setelah buah kopi disortir terlebih dahulu berdasarkan massa jenisnya untuk memperoleh buah kopi yang berkualitas (15). Fermentasi kopi yang banyak dilakukan oleh mayoritas petani adalah fermentasi basah pada buah kopi dengan proses fermentasi alami. Fermentasi kopi agar menghasilkan cita rasa terbaik dilakukan dengan merendam buah kopi dengan air dalam wadah tertutup selama 6-7 hari. Air dalam proses fermentasi berfungsi untuk menyokong pertumbuhan mikroorganisme fermentasi yaitu bakteri asam lakat dan khamir yang secara alami terdapat pada permukaan buah Kopi (16).

Fermentasi kopi pada penelitian ini mengunkaan biji kopi lanang (Peaberry) kering. Biji kopi kering berbeda dengan buah kopi yang dipermukaannya terdapat mikroorganisme alami yang berperan dalam proses fermentasi, sehingga untuk proses fermentasi membutuhkan bantuan enzim. Enzim yang digunakan dalam penelitian yaitu enzim $\alpha$-amilase, selain itu lamanya proses fermentasi mendorong untuk mengembangkan teknologi fermentasi dengan menggunakan paparan medan magnet ELF (Extremely Low Frequency). Medan magnet ELF tergolong dalam radiasi gelombang elektromagnetik yang mempunyai spektrum rendah dengan frekuensi 0-300 Hz dengan energi yang sangat kecil yang dapat menimbulkan efek non thermal (17). Komponen yang menyusun gelombang elektromagnetik terdiri dari medan magnet dan medan listrik (18). Medan magnet mampu menembus sebagian besar material, sedangkan medan listrik memiliki sifat sebaliknya (19).

Penggunaan medan magnet ELF pada penelitian ini bertujuan untuk mempercepat proses fermentasi biji kopi lanang (Peaberry) kering. Medan magnet ELF dapat meningkatkan aktivitas enzim $\alpha$-amilase (20) sehinga kinerja mikroba selama fermentasi menjadi optimal (21). Medan magnet ELF (Extremely Low Frequency) dengan intensitas rendah dapat mengoptimalkan proses fermentasi dengan indikator turunnya nilai $\mathrm{pH}$ fermentasi (13). Hal ini sesuai dengan penelitian sebelumnya yang menunjukkan bahwa paparan medan magnet ELF (Extremely Low Frequency) 
dengan intensitas $200 \mu \mathrm{T}$ selama 60 menit dapat menurunkan $\mathrm{pH}$ fermentasi green coffee robusta (22), sedangkan fermentasi kopi dengan intensitas $400 \mu \mathrm{T}$ selama 30 menit dapat meningkatkan $\mathrm{pH}$ fermentasi kopi liberika (Coffe liberica) (23). $\mathrm{pH}$ merupakan indikator fermentasi kopi, naik turunnya nilai $\mathrm{pH}$ dipengaruhi oleh lama fermentasi, suhu fermentasi (24) dan aktivitas bakteri fermentasi (13). Berdasarkan uraian di atas tujuan dari penelitian ini yaitu meneliti pengaruh paparan medan magnet ELF dengan intensitas $200 \mu \mathrm{T}$ dan $300 \mu \mathrm{T}$ terhadap perubahan $\mathrm{pH}$ pada proses fermentasi biji kopi lanang (Peaberry) kering.

\section{METODE PENELITIAN}

Penelitian dilaksanakan pada bulan Juni di Laboratorium ELF, Program Studi S1 Pendidikan Fisika, Fakultas Keguruan dan Ilmu Pendidikan, Universitas Jember. Jenis penelitian yang digunakan merupakan penelitian eksperimen dengan desain Rancangan Acak Lengkap (RAL) yang bertujuan untuk mengkaji pengaruh perlakuan dengan pengulangan percobaan. Desain penelitian dapat ditunjukkan berdasarkan Gambar 1.

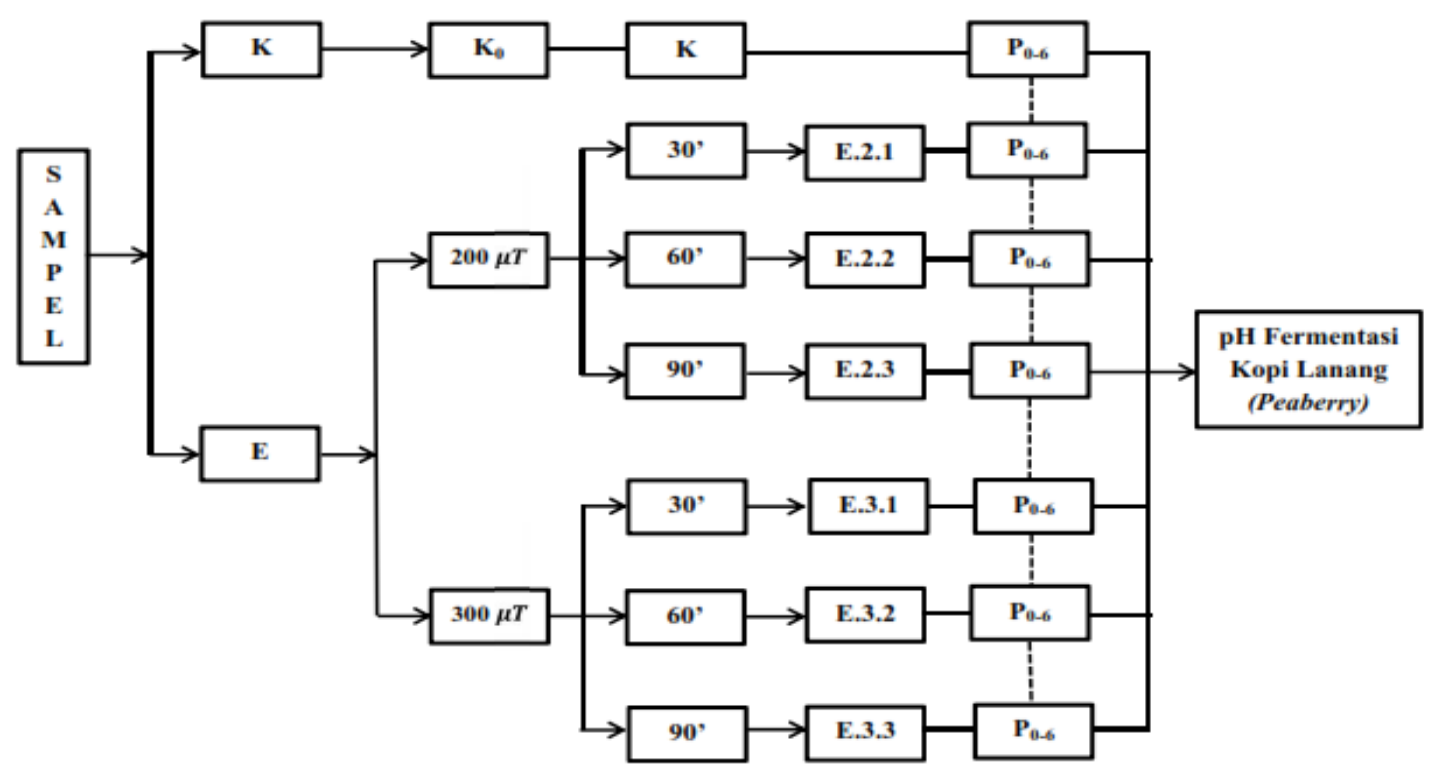

Gambar 1. Desain Penelitian

Penelitian ini mengggunakan sampel biji kopi lanang (Peaberry) kering jenis robusta yang telah difermentasi terlebih dahulu dengan bantuan enzim $\alpha$-amilase. Berdasarkan desain penelitian di atas jumlah sampel penelitian sebanyak tujuh perlakuan yang terbagi ke dalam dua kelompok yaitu satu kelompok kontrol dan enam kelompok eksperimen yang terdiri dari kelompok paparan medan magnet ELF (Extremely Low Frequency) intensitas $200 \mu \mathrm{T}$ dan $300 \mu \mathrm{T}$ dengan lama waktu 30 menit, 60 menit dan 90 menit yang masing-masing sampelnya sebanyak $2 \mathrm{~kg}$. Alat dan bahan dalam penelitian sebagai berikut : alat ELF Electromagnetic Field Source yang terdiri dari Curent Transformer (CT) dan sangkar tembaga berfungsi sebagai penghasil medan magnet ELF, Elektromagnetic field tester (EMF Tester) berfungsi mengukur besar medan magnet yang dihasilkan oleh Curent Transformer (CT), $\mathrm{pH}$ meter berfungsi untuk mengukur $\mathrm{pH}$ pada proses fermentasi biji kopi, neraca digital berfungsi untuk menimbang massa kopi, ember sebagai tempat fermentasi, air aquades dan enzim $\alpha$-amilase digunakan untuk fermentasi biji kopi. Alat ELF Electromagnetic Field Source dapat ditunjukkan berdasarkan Gambar 2. 


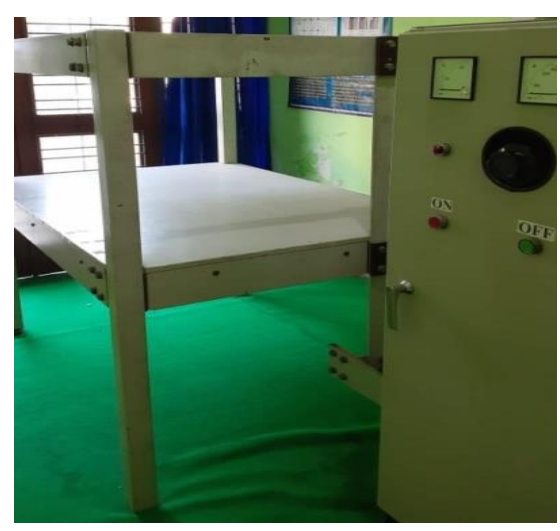

Gambar 2. ELF Electromagnetic Field Source

Penelitian dilaksanakan dengan beberapa prosedur yang diawali dengan mempersiapkan terlebih dahulu alat dan bahan, menentukan dan mengelompokkan sampel dan dilanjutkan dengan fermentasi biji kopi. Fermentasi diawali dengan memilih biji kopi, mencuci bersih biji kopi dan merendam biji kopi dengan air hangat selama 12 jam dan dilanjutkan dengan proses fermentasi. Proses fermentasi dilakukan dengan mencampur $2 \mathrm{~kg}$ biji kopi pada masing-masing sampel dengan 2 liter air aquades dan enzim $\alpha$-amilase sebanyak $2 \mathrm{ml}$ ke dalam ember tertutup, setelah itu didiamkan selama 24 jam untuk selanjutnya di papar dengan medan magnet ELF. Pemaparan disesuaikan dengan pengelompokan sampel berdasarkan intensitas dan waktu pemaparan. Fermentasi biji kopi dilakukan selama 5 hari setelah pemaparan dan nilai $\mathrm{pH}$ fermentasi biji kopi diukur pada hari ke-1, hari ke-2, hari ke-3, hari ke-4 dan hari ke-5 selama proses fermentasi dengan lima kali pengulangan pada masing-masing pengukuran.

Penelitian ini menggunakan metode analisa data statistik deskriptif. Statistik deskriptif merupakan metode analisa data yang digunakan untuk memberikan penjelasan atau mendeskripsikan mengenai suatu keadaan dan dilanjutkan dengan menarik sebuah kesimpulan. Analisis statistik deskriptif dilakukan menggunakan aplikasi IBM SPSS Statistik 22 dan Microsoft Office Excel 2010. Analisis data menggunakan aplikasi IBM SPSS Statistik 22 dengan metode statistik nonparametrik yang menggunakan uji Independent Sampel T-Test-Uji Mann Whitney dan dilanjutkan dengan uji Kruskal Wallis sebagi pengganti uji One Way Anova (25). Hipotesis pada penelitian terdiri dari hipotesis nol $\left(\mathrm{H}_{0}\right)$ yang menyatakan tidak ada perbedaan yang signifikan

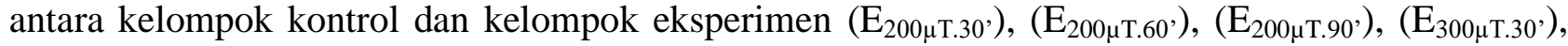
$\left(\mathrm{E}_{300 \mu \mathrm{T} .60^{\circ}}\right),\left(\mathrm{E}_{300 \mu \mathrm{T} .90^{\prime}}\right)$ dan hipotesis alternatif $\left(\mathrm{H}_{\mathrm{a}}\right)$ yang menyatakan ada perbedaan yang signifikan antara kelompok kontrol dan kelompok eksperimen $\left(\mathrm{E}_{200 \mu \mathrm{T} .30^{\circ}}\right),\left(\mathrm{E}_{200 \mu \mathrm{T} .60^{\circ}}\right),\left(\mathrm{E}_{200 \mu \mathrm{T} .90^{\circ}}\right),\left(\mathrm{E}_{300 \mu \mathrm{T} .30^{\prime}}\right)$,

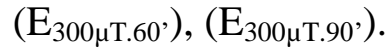

Uji Independent Sampel T-Test-Uji Mann Whitney digunakan untuk mengetahui ada atau tidaknya perbedaan rata-rata dua sampel yang tidak berpasangan dengan kriteria pengujian jika nilai Asymp.Sig (2-tailed) $<0,05$ makan $\mathrm{H}_{0}$ ditolak dan $\mathrm{H}_{\mathrm{a}}$ diterima, sedangkan jika nilai Asymp.Sig (2tailed) > 0,05 makan $\mathrm{H}_{\mathrm{a}}$ ditolak dan $\mathrm{H}_{0}$ diterima (26). Analisis data dilanjutkan dengan uji Kruskal Wallis digunakan untuk mengetahui ada atau tidaknya perbedaan antara beberapa sampel yang tidak berpasangan dengan kriteria pengujian jika nilai Asymp.Sig (2-tailed) $<0,05$ maka $\mathrm{H}_{0}$ ditolak dan $\mathrm{H}_{\mathrm{a}}$ diterima, sedangkan jika nilai Asymp.Sig (2-tailed) > 0,05 makan $\mathrm{H}_{\mathrm{a}}$ ditolak dan $\mathrm{H}_{0}$ diterima (27), sedangkan Microsoft Office Excel 2010 berfungsi untuk mengetahui ada atau tidak perbedaan nilai rata-rata $\mathrm{pH}$ kelompok kontrol dengan kelompok eksperimen berdasarkan diagram batang.

\section{HASIL DAN PEMBAHASAN}

Pengukuran $\mathrm{pH}$ pada sampel fermentasi biji kopi lanang (Peaberry) kering jenis robusta menggunakan alat $\mathrm{pH}$ meter. Pengukuran $\mathrm{pH}$ awal sampel dilakukan sebelum pemaparan atau hari ke-0, kemudian dilanjutkan pada hari ke-1, hari ke-2, hari ke-3, hari ke-4 dan hari ke-5 setelah pemaparan dengan lima kali pengulangan pada masing-masing pengukuran. Berikut adalah hasil pengukuran nilai $\mathrm{pH}$ rata-rata proses fermentasi biji kopi lanang (Peaberry) kering ditunjukkan pada tabel 1. 
Tabel 1. Nilai Rata-Rata $\mathrm{pH}$ proses fermentasi biji kopi lanang (Peaberry) kering

\begin{tabular}{|c|c|c|c|c|c|c|c|}
\hline \multirow[t]{2}{*}{ Kelompok } & \multirow[t]{2}{*}{ Sampel } & \multicolumn{6}{|c|}{$\begin{array}{c}\text { Nilai pH Rata-Rata pH Fermentasi Biji Kopi Lanang } \\
\text { (Peaberry) Pada Hari Ke- }\end{array}$} \\
\hline & & 0 & 1 & 2 & 3 & 4 & 5 \\
\hline Kontrol & $\mathrm{K}$ & 5.17 & 4.69 & 4.63 & 4.83 & 5.13 & 6.17 \\
\hline $\mathrm{E}_{200 \mu \mathrm{T} .30}$ & E.2.1 & 5.17 & 4.70 & 4.61 & 4.78 & 5.30 & 5.93 \\
\hline $\mathrm{E}_{200 \mu \mathrm{T} .60}$ & E. 2.2 & 5.17 & 4.71 & 4.64 & 4.79 & 5.23 & 6.08 \\
\hline $\mathrm{E}_{200 \mu \mathrm{T} .90}$ & E. 2.3 & 5.17 & 4.69 & 4.61 & 4.85 & 5.34 & 6.20 \\
\hline $\mathrm{E}_{300 \mu \mathrm{T} .30}$ & E.3.1 & 5.17 & 4.71 & 4.64 & 4.86 & 5.16 & 6.04 \\
\hline $\mathrm{E}_{300 \mathrm{uT} 60}$ & E.3.2 & 5.17 & 4.71 & 4.67 & 4.90 & 5.73 & 6.01 \\
\hline $\mathrm{E}_{300 \mu \mathrm{T} .90}$ & E.3.3 & 5.17 & 4.68 & 4.62 & 4.92 & 5.21 & 6.12 \\
\hline
\end{tabular}

Berdasarkan pada tabel 1 di atas dapat diketahui bahwa kelompok kontrol dan kelompok eksperimen memiliki nilai rata-rata $\mathrm{pH}$ yang berbeda. Berikut adalah diagram batang hasil analisis melalui Microsoft Office Excel 2010 yang menunjukkan perbedaan nilai rata-rata $\mathrm{pH}$ proses fermentasi biji kopi lanang (Peaberry) kering pada hari ke-0, hari ke-1, hari ke-2, hari ke-3, hari ke4 dan hari ke-5 ditunjukkan oleh gambar 3 dan gambar 4.

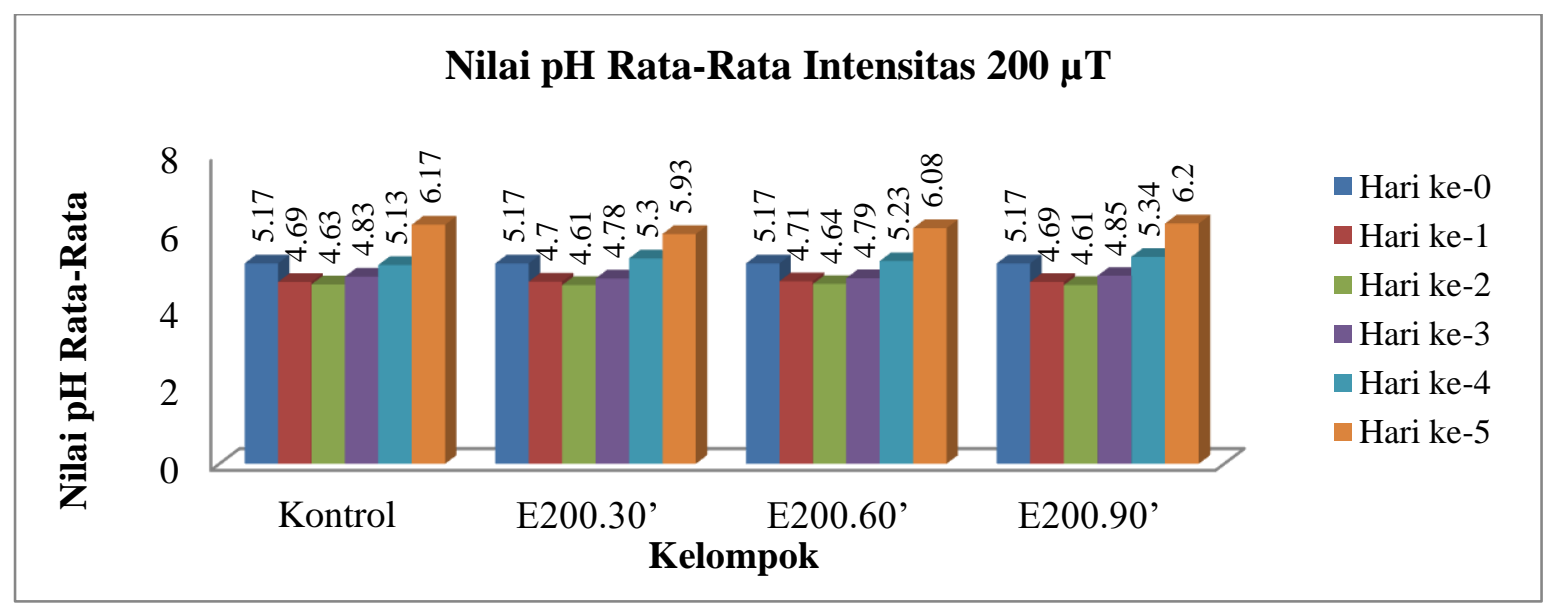

Gambar 3. Nilai pH Rata-Rata Fermentasi Biji Kopi Lanang (Peaberry) Kering Intensitas $200 \mu \mathrm{T}$

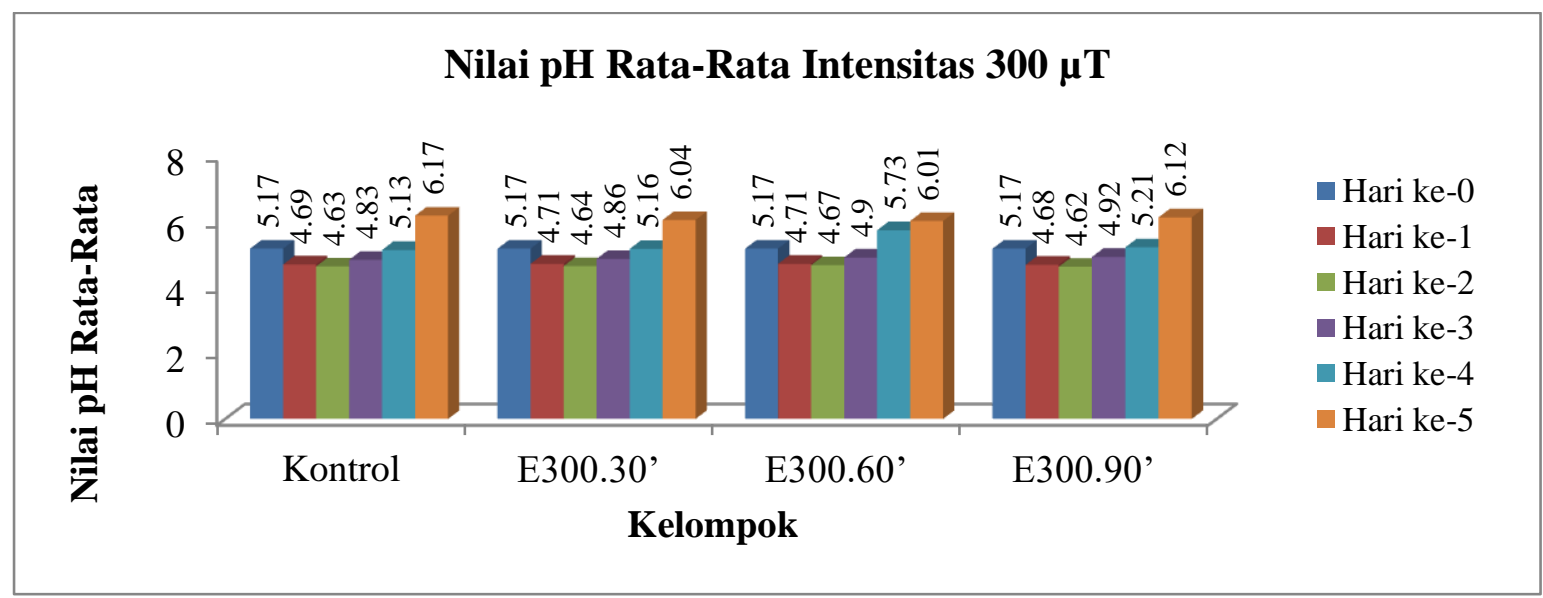

Gambar 4. Nilai pH Rata-Rata Fermentasi Biji Kopi Lanang (Peaberry) Kering Intensitas $300 \mu \mathrm{T}$

Berdasarkan pada gambar 3 dan gambar 4 di atas menunjukkan bahwa nilai pH rata-rata awal fermentasi biji kopi lanang (Peaberry) kering sebelum pemaparan adalah 5,17 dan setelah pemaparan pada hari ke-1 sampai hari ke-2 terjadi penurunan $\mathrm{pH}$ dari kelompok kontrol dan kelompok eksperimen. Nilai $\mathrm{pH}$ rata-rata pada pengukuran hari ke-1 yang paling rendah dari pada kelompok kontrol dengan nilai $\mathrm{pH}$ rata-rata sebesar 4,69 adalah kelompok eksperimen dengan intensitas $300 \mu \mathrm{T}$ dan lama waktu 90 menit yang nilai pHnya 4,68, sedangkan pada hari ke-2 yang 
paling rendah nilai $\mathrm{pH}$ rata-rata dibandingkan kelompok kontrol dengan nilai $\mathrm{pH}$ rata-rata sebesar 4,63 adalah kelompok eksperimen intensitas $200 \mu \mathrm{T}$ dengan lama waktu 30 menit dan 90 menit yang nilai pHnya 4,61. Pengukuran $\mathrm{pH}$ pada hari ke-3 sampai hari ke-5 menunjukkan kenaikan nilai pH pada kelompok kontrol dan kelompok eksperimen. Pengukuran hari ke-3 diperoleh nilai $\mathrm{pH}$ tertinggi dibandingkan kelompok kontrol dengan $\mathrm{pH}$ 4,78 adalah kelompok eksperimen intensitas paparan $300 \mu \mathrm{T}$ dengan lama waktu 90 menit yang nilai pHnya 4,92. Pengukuran hari ke-4 diperoleh nilai $\mathrm{pH}$ tertinggi dibandingkan kelompok kontrol dengan $\mathrm{pH} 5,13$ adalah kelompok eksperimen intensitas paparan $300 \mu \mathrm{T}$ dengan lama waktu 60 menit yang nilai pHnya 5,73 dan pengukuran pada hari ke-5 diperoleh nilai $\mathrm{pH}$ tertinggi dibandingkan kelompok kontrol dengan $\mathrm{pH}$ 6,17 adalah kelompok eksperimen intensitas paparan $200 \mu \mathrm{T}$ dengan lama waktu 90 menit yang nilai pHnya 6,20.

Hasil pengukuran nilai pH rata-rata Fermentasi biji kopi lanang (Peaberry) kering pada penelitian ini berbeda dengan penelitian yang dilakukan oleh Kanza (2020) dan Anam (2020). Kanza (2020) menyatakan bahwa nilai $\mathrm{pH}$ rata-rata fermentasi basah kopi liberika mengalami penurunan pada hari ke-1 sampai hari ke-3 dan mengalami kenaikan nilai $\mathrm{pH}$ rata-rata pada hari ke4 sampai hari ke-5, penurunan nilai $\mathrm{pH}$ rata-rata paling signifikan terjadi pada intensitas paparan medan magnet $400 \mu \mathrm{T}$ dengan lama waktu pemaparan 60 menit dan peningkatan nilai $\mathrm{pH}$ rata-rata paling signifikan terjadi pada intensitas paparan medan magnet $400 \mu \mathrm{T}$ dengan lama waktu pemaparan 30 menit (23). Anam (2020) dalam penelitiannya terkait fermentasi biji kopi green coffee robusta menyatakan bahwa intensitas $200 \mu \mathrm{T}$ selama 60 menit dapat menurunkan nilai $\mathrm{pH}$ fermentasi (22).

Data hasil penelitian selain dianalisis dengan menggunakan Microsoft Office Excel 2010 dalam bentuk diagram batang juga dianalisis dengan menggunakan IBM SPSS Statistik 22. Analisis data diawali dengan melakukan uji normalitas data menggunakan analisis Kolmogorov Smirnov dengan hasil nilai Asymp. Sig. (2-Tailed) < 0.05 yang menyatakan bahwa data tidak berdistribusi normal. Data yang tidak berdistribusi normal akan dianalis menggunakan metode statistik nonparametrik dengan uji Independent Sampel T-Test-Uji Mann Whitney dan dilanjutkan dengan uji Kruskal Wallis sebagi pengganti uji One Way Anova (Hasan, 2004). Hasil uji Independent Sampel T-TestUji Mann Whitney menunjukkan bahwa nilai Asymp. Sig (2-tailed) sampel kelompok eksperimen $\mathrm{E}_{200} \mu \mathrm{T} .30, \mathrm{E}_{200} \mu \mathrm{T} .60, \mathrm{E}_{300} \mu \mathrm{T} .30, \mathrm{E}_{300} \mu \mathrm{T} .60$, $\mathrm{E}_{300 \mu \mathrm{T} .90}$, pengukuran pada hari ke-1, kelompok eksperimen $\mathrm{E}_{200 \mu \mathrm{T} .30}$, $\mathrm{E}_{200} \mu \mathrm{T} .60^{\prime}, \mathrm{E}_{200 \mu \mathrm{T} .90}$, $\mathrm{E}_{300 \mu \mathrm{T} .30}, \mathrm{E}_{300} \mu \mathrm{T} .60$, $\mathrm{E}_{300 \mu \mathrm{T} .90}$, pengukuran pada hari ke2, hari ke-3, hari ke-4, dan hari ke-5 menunjukkan kurang dari 0,05. Nilai Asymp. Sig. (2-tailed) < 0,05 menyatakan $\mathrm{H}_{\mathrm{a}}$ diterima dan $\mathrm{H}_{0}$ ditolak sehingga dapat diartikan bahwa ada perbedaan nilai $\mathrm{pH}$ yang signifikan antara kelompok kontrol dan kelompok eksperimen, sedangkan sampel kelompok eksperimen $\mathrm{E}_{200.90}$, pengukuran pada hari ke-1 menunjukkan nilai Asymp. Sig. (2-tailed) >0,05. Nilai Asymp. Sig. (2-tailed) > 0,05 menyatakan $\mathrm{H}_{0}$ diterima dan $\mathrm{H}_{\mathrm{a}}$ ditolak sehingga dapat diartikan bahwa tidak ada perbedaan nilai $\mathrm{pH}$ yang signifikan antara kelompok kontrol dan kelompok eksperimen. Analisis data nilai $\mathrm{pH}$ fermentasi biji kopi lanang (Peaberry) kering setelah uji Independent Sampel T Test-uji Mann Whitney dilanjutkan dengan uji Kruskal Wallis. Hasil uji Kruskal Wallis menyatakan bahwa nilai Asymp. Sig. (2-tailed) pada setiap pengukuran sebesar 0,000 yang menunjukkan kurang dari 0,05. Nilai Asymp. Sig. (2-tailed) $<0,05$ menyatakan $\mathrm{H}_{\mathrm{a}}$ diterima dan $\mathrm{H}_{0}$ ditolak sehingga dapat diartikan bahwa ada perbedaan nilai $\mathrm{pH}$ yang signifikan antara kelompok kontrol dan kelompok eksperimen $\mathrm{E}_{200} \mu \mathrm{T} .30^{\prime}, \mathrm{E}_{200} \mu \mathrm{T} .60^{\prime}, \mathrm{E}_{200} \mu \mathrm{T} .90^{\prime}, \mathrm{E}_{300} \mu \mathrm{T} .30^{\prime}, \mathrm{E}_{300}$ $\mu \mathrm{T} .60$, $\mathrm{E}_{300 \mu \mathrm{T} .90}$.

Peningkatan dan penurunan nilai pH pada fermentasi biji kopi lanang (Peaberry) kering terjadi karena paparan medan magnet ELF yang menyebabkan perubahan ion ekstraseluler mikroorganisme fermentasi (bakteri aerobik, bakteri asam laktat, Enterobacteriaceae, yeast dan jamur berfilamen) yang melintasi membran sehingga dapat meningkatkan pergerakan ion yang melalui daerah fluks magnetik. Ion dalam sel yang dapat terpengaruh adalah $\mathrm{Ca}^{2+}$, karena ion ini bersifat paramagnetik sehingga dapat terpengaruh oleh medan magnet yaitu terarahnya spin elektron (28). Medan magnet ELF (Extremely Low Frequency) dapat menyebabkan perubahan kecepatan ion $\mathrm{Ca}^{2+}$ ekstraseluler melewati membran sel, sehingga jika kebutuhan ion $\mathrm{Ca}^{2+}$ cepat Pengaruh Paparan Medan Magnet Extremely Low Frequency (Elf) terhadap Perubahan PH pada Proses Fermentasi....

Mamik Purbawati, Sudarti, Firdha Kusuma A. A. 
terpenuhi maka proses pertumbuhan sel akan semakin cepat dan meningkatkan pertumbuhan bakteri (29). Meningkat atau menurunya jumlah bakteri asam laktat (Lactobacillus) pada proses fermentasi berkaitan dengan naik atau turunnya nilai $\mathrm{pH}$ (13).

\section{SIMPULAN DAN SARAN}

Hasil dan pembahasan dalam penelitian ini menjadi dasar untuk menarik kesimpulan yaitu paparan medan magnet ELF dapat mempengaruhi perubahan nilai $\mathrm{pH}$ pada proses fermentasi biji kopi lanang (Peaberry) kering jenis robusta dengan penambahan enzim $\alpha$-amilase. Berdasarkan penelitian sebelumnya dapat diketahui bahwa medan magnet ELF (Extremely Low Frequency) dengan intensitas rendah berpengaruh dalam mempercepat penurunan $\mathrm{pH}$ fermentasi kopi. Hasil penelitian berupa grafik yang bervariasi menunjukkan bahwa nilai $\mathrm{pH}$ rata-rata fermentasi biji kopi lanang (Peaberry) kering terjadi penurunan pada hari ke-1 sampai hari ke-2 dan mengalami kenaikan pada hari ke-3 sampai hari ke-5 yang disebabkan oleh adanya bakteri fermentasi. Berdasarkan hasil penelitian dan pembahasan dapat diberikan saran yaitu perlu adanya pengembangan terkait dengan variasi intensitas pemaparan, lama pemaparan, teknik fermentasi dan jenis kopi yang digunakan dalam proses fermentasi.

\section{DAFTAR PUSTAKA}

1. Widodo N, Ari D. Pengaruh Nilai Tukar dan Tingkat Inflasi Terhadap Ekspor Kopi dan Dampaknya Terhadap Pertumbuhan Ekonomi. J Administrasi Bisnis. 2020; 78(1) : 19-27.

2. Sa'diah K, Maulida H. Pengaruh Konsumsi Kopi (Coffa sp.) Terhadap pH, Laju Alir dan Viskositas Saliva Pada Pecandu Kopi (Coffee Holic). J B-Dent.2018; 5(1):72-82.

3. Wirama AN, Yunus M, Andiana O. Dampak Pemberian Kafein Terhadap Hasil Tes Kecepatan Dan Tes Kelincahan Mahasiswa Ilmu Keolahragaan Universitas Negeri Malang. J Sport Sci. 2019;9(2):131.

4. Yonata A, Saragih DGP. Pengaruh Konsumsi Kafein pada Sistem Kardiovaskular. J Major. 2016;5(3):43-9.

5. Tika IN, Pujani NM, Agustiana IGAT, Agustriana T. Kafein Pada Kopi Dengan Fermentasi Menggunakan Mikroba Yang Diisolasi Dari Kopi Kotoran Luwak Kebun Kopi Di Kabupaten Buleleng. Semin Nas Ris Inov 2017. 2017;2015:839-46.

6. Imama AN, Rosyid R, Rika ES. Pengaruh Penambahan Kulit Kopi Kering Terhadap Penurunan Kadar Kafein Pada Kopi Lanang (Peaberry Coffee). 2019; 1(2): 11-22.

7. Aditya IW, Nocianitri KA, Yusasrini NLA. Kajian Kandungan Kafein Kopi Bubuk, Nilai pH dan Karakteristik Aroma dan Rasa Seduhan Kopi Jantan (Pea berry coffee) dan Betina (Flat beans coffee) Jenis Arabika dan Robusta. J Ilmu dan Teknol Pangan. 2016;5(1):1-12.

8. Anggarai R. Identifikasi Morfologi Kopi Lanang (Peaberry) dan Kopi Biasa Robusta Lampung. Skripsi. Universitas Lampung : Bandar Lampung; 2018.

9. Wahono B. Effects of Peaberry Coffee on the Sexual Behavior ang The Blood Testoterone Levels of The Male Mouse (mus musculus). Proceeding of 3nd International Conference on Research, Implementation and Education of Mathematics and Science; 2016.p. 21-5.

10. Wahyudi R. Studi Penggunaan Metode Analisis Berbasis UV-Vis Spectroscopy dan Metode Regresi PLS untuk Penentuan Konsentrasi Kopi Campuran Lanang-Biasa (Peaberry dan Normal). Skripsi. Lampung : Universitas Lampung; 2018.

11. Farida A, Evi R, Andri CK. Penurunan Kadar Kafein dan Asam Total Pada Biji Kopi Robusta Menggunakan Tegnologi Fermentasi Anaerob Fakultatif dengan Mikroba Nopkor MZ-15. J Tegnologi Kimia dan Industri. 2013; 70-5. 
12. Hanifah N, Kurniawati D. Pengaruh Larutan Alkali dan Yeast terhadap Kadar Asam, Lemak dan Kafein pada Proses Pembuatan Kopi Fermentasi. J Tegnologi Kimia dan Industri. 2013; $2(2): 162-8$.

13. Sudarti, Bektiarso S, Prastowo SHB, Prihandono T, Maryani dan Rif'ati DH. Optimizing Lactobacillus Growth in the Fermentation Process of Artificial Civet Coffee Using Extremely Low Frequency (ELF) Magnetic Field. Journal of Physics : Conference Series. 2020; 1-6.

14. Lin CC. Approach of Improving Coffee Industry in Taiwan-Promote Quality of Coffee Bean by Fermentation. The Journal of International Management Studies. 2010; 5(1): 154-9.

15. Ardi H. Pengawasan Mutu terhadap Biji Kopi Pada Proses Sortasi di Kelompok Tani Rahayu IV Dusun Kopi Sirap Kecamatan Jambu Kabupaten Semarang. Laporan Kerja Praktik. Semarang : Tegnologi Pertanian Universitas Katolik Soegijapranata; 2018.

16. Towaha J, Rubiyo. Mutu Fisik dan Citarasa Kopi Arabika Hasil Fermentasi Mikrob Probiotik Asal Pencernaan Luwak. J. TIDP. 2016; 3(2): 61-70.

17. Agustina SD, Sri HBP, Sudarti. Analisis Intensitas Medan Magnet Extremely Low Frequency (ELF) di Sekitar Laptop. J Pembelajaran Fisika. 2018; 7(3) : 286-92.

18. Young HD, Freedman RA. Fisika Universitas. Jilid 1 Edisi 10. Jakarta : Erlangga; 2002.

19. Sudarti, Singgih B, Sri HBP. Radiation Potential of Extremely Low Frequency (ELF) Magntic Field to Increase Tobacco Production. International Journal of Enginering and Technology. 2018; 10(6): 2319-8613.

20. Handoko, Sudarti, Rif'ati DH. Analisis Dampak Paparan Medan Magnet Extrmely Low Frequency (ELF) Pada Biji Cabai Merah Besar (Capsicum annum. L) Terhadap Pertumbuhan Tanaman Cabai Merah Besar (Capsicum annum. L). J Pembelajaran Fisika. 2017; 5(4): 370-7.

21. Fauzi M, Miftahul C, Yuli DPA. Karakteristik Kimia Kopi Luak Robusta Artifisial Terfermentasi Oleh Ragi Luak dan A-Amilase. J Penelitian Pascapanen Pertanian. 2017;14(3): 144-53.

22. Anam MAK. Pengaruh Paparan Medan Magnet ELF (Extremely Low Frequency) terhadap Peningkatan Nilai pH dan Daya Hantar Listrik dalam Proses Fermentasi Green Coffee Robusta. Skripsi. Jember : Universitas Jember; 2020.

23. Kanza NRF, Sudarti, Maryani. Pengaruh Paparan Medan Magnet Extremely Low Frequency (ELF) terhadap pH dan Daya Hantar Listrik pada Proses Fermentasi Basah Kopi Liberika (Coffea liberica) dengan Penambahan Enzin $\alpha$-amilase. J Hasil Kajian, Inovasi dan Aplikasi Pendidikan Fisika. 2020; 6(2): 315- 21.

24. Febrianti D. Pengaruh Suhu dan Waktu terhadap Fermentasi Biji Kopi. Seminar Nasional Pendidikan Fisika; 2019.p. 54-6.

25. Hasan I. Analisis Data Penelitian dengan Statistik. Jakarta : Bumi Aksara, 2004.

26. Hadjar I. Statistik. Bandung : PT Remaja Rodaskarya, 2019.

27. Sulaiman W. Statistik Non-Parametrik. Yogyakarta : ANDI Yogyakarta; 2005.

28. Sutrisno, Gie. Fisika Dasar : Listrik Magnet dan Termofisika. Bandung : Institut Tegnologi Bandung; 1979.

29. Gaafar EA, Hanafy MS, Tohamy EY, Ibrahim MH. Stimulation and control of E. coli by usingv an extremely low frequency magnetic field. Rom J Biophys, Bucharest. 2006;16(4):283-96. 